\title{
Foreign Language Listening Anxiety: Its Dimensionality and Group Differences
}

\section{Harumi Kimura Temple University Japan}

This paper investigates foreign language listening anxiety (FLLA) in line with social and interpersonal anxiety studies. Language-learning anxiety has been conceptualized as a unique, situation-specific entity, and recent research in second language acquisition (SLA) has examined anxiety with respect to such skill domains as reading and writing as well as in terms of spoken interaction. Too much emphasis on specificity, however, might have led researchers and practitioners to miss common features of anxiety as affective processes under tension. A Japanese translation of the Foreign Language Listening Anxiety Scale (FLLAS), which was created for Korean learners of English by Kim (2000), was administered to 452 Japanese learners. Data reduction through factor analysis indicated that this construct, as measured by the FLLAS, has three factors which were labeled Emotionality, Worry, and Anticipatory Fear. University major and gender were chosen as independent variables, and only the levels of the former were found to be significantly different in terms of one of the factors, Emotionality. Math students experienced more arousal of fear than social science students in this dimension of the FLLAS.

本論文は、日本人の英語学習者がリスニングを行う際どのような不安を覚えるかを調査したも のである。韓国語を母語とする英語学習者向けに開発された尺度の日本語版を実施しその結果 を因子分析および分散分析を用いて分析した。その結果、専攻分野によって学習者の不安には 異なる型が認められることがわかった。その他の結果もあわせてモデルの構築を行った。

JALT Journal, Vol. 30, No. 2, November, 2008 
7 he impact of affect and emotional arousal in language learning has long been underestimated and under-researched with motivation and anxiety being the main exceptions. Language-learning anxiety can be defined as "the feeling of tension and apprehension specifically associated with second-language contexts" (MacIntyre \& Gardner, 1994b, p. 284). Much of the past research has been conducted on the aspect of anxiety associated with oral production in L2, but recently interest has been extended to cover all of the four skill areas: speaking, writing, reading, and listening. The trend has been toward emphasizing the independent, distinguishable aspects of this affective construct in each of the four skill areas and the situation-dependent nature of anxiousness felt in specific contexts. For example, Matsuda and Gobel (2001; 2004) studied foreign language reading anxiety (FLRA) and suggested that foreign language classroom anxiety (FLCA) and FLRA were distinct, although they apparently shared an important sub-component: (lack of) self-confidence. In this paper, one of the skill-based constructs, foreign language listening anxiety (FLLA), is investigated to explore the internal structure of this psychological construct using the statistical method of factor analysis, and the identified factors are investigated in relation to two distinct variables, university major and gender, to examine group differences.

\section{Literature Review}

As reviewed by MacIntyre (1999; 2002), Horwitz (2001), and Dörnyei (2002; 2005), anxiety has established itself as one of the important variables responsible for individual differences in the success or failure of secondlanguage learning. The concept of language-learning anxiety is relatively new, however, and Horwitz, Horwitz, and Cope (1986) were among the first to bring this affective variable into the SLA research trajectory, creating what they called the Foreign Language Classroom Anxiety Scale (FLCAS). From the beginning, there has been debate over whether the specific type of nervous feeling associated with foreign language learning could be a transfer from, or a composite of, other types of anxiety, such as test anxiety, general trait anxiety, social anxiety, and communication apprehension (Horwitz, 1986; Kitano, 2001; Kleinmann, 1977; MacIntyre, 1999; MacIntyre \& Gardner, 1989; Scovel, 1978). The current consensus is that language anxiety should be seen as a situation-specific construct-i.e., a distinct type of anxiety. An emotionally stable person may be nervous in the languagelearning context, while on the other hand a person with a predisposition to anxiety may not show significant nervousness in language learning. 
Interestingly, the experimental study of MacIntyre and Gardner (1994a) unwittingly indicated that language-learning anxiety could also be induced by a non-linguistic, task-irrelevant stimulus. In this study, a video camera was put in a computer lab to artificially create an anxietyprovoking learning environment, and it "successfully" helped to impair language learning -in this case, computer-mediated vocabulary learning. Although language-learning anxiety might be situation- and task-specific and also independent of other types of anxiety to a certain extent, L2 learners seem to become nervous in ways that parallel other threatening situations. This can be inferred from the physiological, cognitive, and emotional reactions detected and examined in test anxiety-another performance anxiety (Zeidner, 1998) —and also in social anxiety (Leary \& Kowalski, 1995).

Less-focused attention, less-effective information processing, and poorer retrieval of prior knowledge are noticeable features of poor performance in L2 listening (Arnold, 2000; Vogely, 1998). L2 listeners cannot manage or control the input and are at the mercy of the delivery of speech unless they are skillful enough to request that the input be slowed down, repeated, or clarified. In other words, they may be overloaded with unprocessed aural information. Listeners in L2 worry about misunderstanding or non-understanding, and they fear embarrassing outcomes (MacIntyre, 1995). Kim (2000) studied this specific type of anxiety, FLLA, but two things are worth noting. First, Kim's study was in line with other works of research that investigated domain-specific anxiety other than speaking anxiety in L2-e.g., Cheng, Horwitz, and Schallert (1999) in writing and Matsuda and Gobel (2001; 2004); Saito, Horwitz, and Garza (1999); and Young and Oxford (1997) in reading. These studies demonstrated the skill-specific characteristics of language-learning anxiety. Second, Kim used the FLCAS as a model for the development of his instrument, along with Wheeless's (1975) Receiver Apprehension Test, primarily in order to compare the construct of L2 listening anxiety with that of L2 interaction anxiety that is experienced in instructed learning situations. A considerable number of the items in the FLCAS and the FLLAS correspond between the listening and classroom-interaction domains. For example, Item 9 of the FLLAS and Item 8 of the FLCAS both refer to testing situations. Distraction is the issue on Item 7 of the FLLAS and Item 6 of the FLCAS. Moreover, one of the reverse items of the FLLAS, Item 14, is almost identical across domains to Item 18 of the FLCAS as shown below: 
Item 14 of the FLLAS: I feel confident in my listening skills.

Item 18 of the FLCAS: I feel confident when I speak in foreign [-language] class.

Kim's (2000) doctoral dissertation involved extensive research, in which she observed that past anxiety studies had focused on overall second-language skills, not on listening per se. To investigate the nature and characteristics of FLLA, the author used (1) factor analyses of the FLLAS and the FLCAS; (2) MANOVAs by gender and major, among others; and (3) correlation analyses between anxiety scores and listening scores. The FLLAS was created in Korean, and the initial 41 items were rated for content validity by five Ph.D students in foreign language education at the University of Texas. The criterion for retaining items was $80 \%$ agreement for each of the four categories: fear of listening to spoken English, process-related anxiety, lack of self-confidence, and apprehension of insufficient prior knowledge. The instrument was piloted on "a sample of 36 Korean ESL students and their spouses, all of whom were university or college graduates" (Kim, 2000, p. 63). Eight items were removed after the analysis based on item-scale correlations, and the final instrument, consisting of 33 five-point Likert-scale items, was administered to a total of 253 Korean EFL students. Evidence of concurrent validity was established in Kim's study by examining correlations with scores of other instruments that measured related variables. The internal consistency estimate of reliability for the questionnaire was .93, and the test-retest reliability was .84 . The items were translated into English by the author and modified by a colleague for easier understanding and clarification.

One of the main findings of Kim (2000) was the two-factor solution of her factor analysis of the FLLAS. She labeled the two factors "Tension and Worry over English Listening" and "Lack of Confidence in Listening," respectively, and she found no significant differences in gender or major (humanities and non-humanities majors) in terms of the two factors. The only significant difference was found in study experience in private language institutes or with private tutors in terms of the second factor, Lack of Confidence in Listening. However, she used the two factors of the FLLAS, along with the five factors of the FLCAS, for as dependent variables in her MANOVAs and made quite a few comparisons. In reviewing this study, I argue that she may have missed differences when there actually were some. It is important, however, that she also investigated the correlation between the students' FLCAS and FLLAS scores and found that half of the variance of the FLLAS was explained by the FLCAS ( $r=$ 
$\left..71 ; r^{2}=.50\right)$. However, she did not show in what ways FLCA and FLLA were similar and different-i.e., how they are related and how they are distinct. She also found a moderate association between listening anxiety and listening proficiency $(r=-.36)$ and demonstrated the somewhat obvious case "that listening anxiety actually interferes with foreign language listening" (p. 149).

In the current study, I narrow down Kim's research scope and study only the essential properties of the FLLA of Japanese university students in order to search for an appropriate measurement model for this construct using the FLLAS. These properties or features, which are identified as extracted factors, are investigated in relation to two independent variables: gender and university major. One of the independent variables, gender, has been commonly used in research but has produced mixed results in this area so far (Campbell, 1999; Kitano, 2001; MacIntyre, Baker, Clement, \& Donovan, 2002; Young \& Oxford, 1997). For example, Campbell (1999) found that male learners were more anxious but that there was an interaction effect with the time element on participants at the U.S. Defense Language Institute with a variety of L1s. After two weeks of intensive language training, male students felt more anxious while female students got slightly less anxious. Kitano's (2001) study of American learners of Japanese showed that self-perception of language skills affected the anxiety levels of male students but not those of female students in performing speaking tasks. In the Japanese context, Matsuda and Gobel (2004) did not detect any gender differences on the FLCAS or the FLRAS for their participants as a whole (first- to third-year university English majors) but found a difference among the first-year students. It might be safer to say that gender is one of the mediating factors and that a variety of variables are involved both in the level of anxiety and in the make-up of anxiety constructs. It is also interesting to point out that gender difference has produced "inconsistent and inconclusive" results in the studies of social anxiety (Leary \& Kowalski, 1995, p. 123).

The other independent variable examined in this study is academic major. This variable has not been used in anxiety studies but should be examined because it could influence learners' studying orientations or attitudes toward learning. Humanities majors and science majors were compared in a study conducted by Andreou, Andreou, and Vlachos (2004) investigating the relationships among different tasks and the performance of students with different academic orientations. The academic departments the learners were in were also shown to be related to different approaches to studying in Ramsden and Entwistle (1981). 
The research questions in this study were as follows:

1. What is an appropriate measurement model for scores generated by the Japanese-language version of this instrument?

2. How do students in different academic majors differ in terms of listening anxiety?

3. How does gender affect the sub-components of listening anxiety?

\section{Method}

\section{Participants}

A total of 452 students at a university in Japan participated in this study. All of the students were freshmen, and they were grouped into 20 separate English Communication classes, with approximately 25 in each class. There were 309 males and 143 females, and they were either social science (bunkei) majors (251) or math (rikei) majors (201). The social science majors met three times a week to have a 90-minute class, and the math majors met twice a week for the same period of time. Each time they met, the students studied with a native English teacher for 45 minutes to practice speaking, and then they spent another 45 minutes in a language lab where a non-native instructor worked with them on pronunciation, intonation, and listening comprehension skills. For the cross-tabulation of participants, see Table 1 .

Table 1. Cross-Tabulation of Participants

\begin{tabular}{|l|c|c|c|}
\hline & \multicolumn{2}{|c|}{ Gender } & Total \\
\hline & Male & Female & \\
\hline Major & 143 & 106 & 249 \\
\hline Social Science & $(143)$ & $(108)$ & $(251)$ \\
\hline Math & 165 & 35 & 200 \\
\hline & $(166)$ & $(35)$ & $(201)$ \\
\hline Total & 308 & 141 & 449 \\
\hline & $(309)$ & $(143)$ & $(452)$ \\
\hline
\end{tabular}

Note: The original numbers of participants for factor analysis are in parentheses. Three outliers were excluded for two-way ANOVA analyses. 


\section{Materials}

The original version of the instrument (the FLLAS) was developed by Kim (2000). The items were translated by the author and modified by a colleague in pursuit of "naturalness" in the Japanese translation. One of the challenges of translating this instrument was deciding on the terms to use for expressing the "anxious feelings" of L2 listeners. The English version translated from Korean used a variety of words to show anxiousness: worried, worry, nervous, confused, uncomfortable, fear, upset, tense, uneasy, annoyed, and frightened. Among them, "worried" was used most often. The Japanese version had less variety, with only seven terms. For example, the verbs "fear" and "worry" are expressed with the same word, "fuan-ni-naru." These differences might have had subtle but significant influences on the endorsement of the participants. The full Japanese translation of the FLLAS (FLLAS-J) can be found in Appendix $\mathrm{A}$, and a back-translation into English is in Appendix B. The words for anxious feelings in the original were kept intact in the back-translation and are indicated in boldface type.

\section{Procedures}

The instrument was administered in class on the last day of the course, at the end of the second semester in the academic year of 2006, so as to partly reflect what had been encountered in the communicative English course. The 33-item questionnaire took most of the students about five minutes to complete. The students then answered three more open-ended questions, based on their answers on the scale, which were designed to have them look back at their activities and performance in the listening section of the course over the previous three months. The entire procedure took about 15 minutes of their class time. Only the survey results were used in this study.

\section{Results}

In order to investigate the latent structure of the questionnaire, a principal-components analysis was conducted. Seven components with eigenvalues of 1.0 or above were extracted. However, the EV $>1$ rule tends to overestimate the number of factors that should be retained (Henson \& Roberts, 2006). There was a sharp decline after the third component (eigenvalue 1.53) according to the scree plot. Kim's original research extracted a two-factor solution, but in this study the items loading on 
the third factor were rather high (.72 on average) and indicated a shared latent construct which was "anticipated apprehension." Based on inspection of the scree plot and the interpretability of the factor solution, it was decided that a three-factor solution should be rotated. The total amount of item variance accounted for by the three components was $38.55 \%$ : the first factor accounted for $27.78 \%$ of the variance, the second factor for $6.23 \%$, and the third for $4.63 \%$. The identities of the chosen factors and the variance accounted for are examined in the discussion section.

Principal-axis factoring was then conducted using an orthogonal rotation (varimax) consistent with findings in social psychology that there are distinct dimensions to anxiety (Morris, Davis, \& Hutchings, 1981; Liebert \& Morris, 1967). The appropriateness of the data matrix for factor analysis was checked using the KMO and Barlett's tests (Field, 2005). The KMO test showed a value of .92, and the Barlett's test of sphericity indicated a significance level of .00. These results suggested that the items were sufficiently correlated that factor analysis could yield reliable factors. Seven items, which were loaded below .40, were considered weak or double-loaded, and were eventually taken out (Field, 2005). The minimum loading criterion for retention of items in the measurement model was .43 (Table 2). Cronbach's alphas were .85 for the first factor, .85 for the second factor, and 0.80 for the last factor. Cronbach's alpha for the entire 26-item instrument was .91. Item communality with respect to the three factors is reported in Table 2.

In the original study by Kim (2000), two factors were extracted. One (Factor 1) was named "Lack of confidence in listening," and the other (Factor 2) was labeled "Tension and worry over English listening." I modified these to simply Emotionality and Worry, mainly because these terms better fit the emotional and cognitive dimensions of anxiety which have been elucidated in the field of educational psychology (e.g., Morris, et al., 1981). It should also be noted that a third factor (Factor 3), Anticipatory Fear, was identified in this study. One last fact to report was that the Emotionality component came as the first factor in this study, whereas it was the second in Kim's study.

Following the factor analysis and development of a measurement model for the instrument, three two-way ANOVAs were conducted to investigate the relationship between the academic areas of interest of the learners and their gender, and the three factors identified in the measurement model for the instrument. The Bonferroni method was employed to adjust the $p$ values for the three ANOVAs, and the significance level was $p<.017$. Three univariate outliers were identified on the basis that 
Table 2. Factor Loadings from Principal-Axis Factoring for FLLAS: Communalities and Percentages of Variance

\begin{tabular}{|c|c|c|c|c|}
\hline & \multicolumn{3}{|c|}{ Factor loading } & \multirow{2}{*}{ communality } \\
\hline & 1 & 2 & 3 & \\
\hline item 6 & .45 & .13 & .02 & .22 \\
\hline item 10 & .43 & .24 & .13 & .26 \\
\hline item 11 & .49 & .30 & .27 & .40 \\
\hline item 12 & .64 & .15 & .14 & .45 \\
\hline item 14 & .53 & .12 & .06 & .30 \\
\hline item 15 & .46 & .29 & .22 & .35 \\
\hline item 17 & .44 & .37 & .28 & .41 \\
\hline item 19 & .46 & .31 & -.01 & .30 \\
\hline item 20 & .55 & -.04 & .21 & .35 \\
\hline item 29 & .53 & .36 & .23 & .46 \\
\hline item 30 & .43 & .18 & .14 & .23 \\
\hline item 31 & .53 & .10 & .06 & .29 \\
\hline item 32 & .51 & .16 & .12 & .30 \\
\hline item 1 & .35 & .46 & -.01 & .34 \\
\hline item 2 & .07 & .54 & .00 & .30 \\
\hline item 4 & .29 & .51 & .18 & .38 \\
\hline item 5 & .15 & .46 & .29 & .32 \\
\hline item 7 & -.00 & .57 & .09 & .33 \\
\hline item 9 & .28 & .55 & .14 & .44 \\
\hline item 16 & .20 & .50 & .28 & .37 \\
\hline item 18 & .32 & .53 & .03 & .39 \\
\hline item 21 & .38 & .50 & .16 & .42 \\
\hline item 23 & .25 & .56 & .23 & .43 \\
\hline item 33 & .29 & .53 & .19 & .39 \\
\hline item 26 & .18 & .24 & .67 & .53 \\
\hline item 27 & .19 & .21 & .77 & .67 \\
\hline item 3 & .31 & .25 & .12 & .17 \\
\hline item 8 & -.03 & .33 & .18 & .14 \\
\hline item 13 & .18 & .20 & .36 & .20 \\
\hline item 22 & .26 & .39 & .19 & .25 \\
\hline item 24 & .11 & .34 & .26 & .20 \\
\hline item 25 & .28 & .00 & .21 & .12 \\
\hline item 28 & .24 & .28 & .09 & .14 \\
\hline$\%$ of variance & 29.01 & 4.74 & 3.51 & 37.28 \\
\hline
\end{tabular}

Note: $N=452$. Boldface indicates factor loadings higher than .40 . 
Table 3. Descriptive Statistics of Items in FLLAS in Terms of Factors and Reliability of the Scale, Factors, and Items

\begin{tabular}{|c|c|c|c|c|c|}
\hline & $N$ & $M$ & $S D$ & $\alpha$ & Total \\
\hline FLLAS-J & 452 & 92.83 & 16.59 & .91 & 130 \\
\hline Factor 1 & 452 & 46.23 & 8.72 & .85 & 65 \\
\hline$(-) 6$ & 452 & 3.73 & 1.07 & .84 & 5 \\
\hline 10. & 452 & 3.89 & 1.11 & .84 & 5 \\
\hline 11. & 452 & 3.43 & 1.19 & .84 & 5 \\
\hline 12. & 452 & 3.89 & 1.22 & .83 & 5 \\
\hline (-) 14 . & 452 & 4.25 & .99 & .83 & 5 \\
\hline 15. & 452 & 3.35 & 1.17 & .84 & 5 \\
\hline 17. & 452 & 3.33 & 1.21 & .84 & 5 \\
\hline 19. & 452 & 3.45 & 1.27 & .84 & 5 \\
\hline 20. & 452 & 3.78 & 1.29 & .84 & 5 \\
\hline 29. & 452 & 3.97 & 1.01 & .83 & 5 \\
\hline 30. & 452 & 3.24 & 1.30 & .84 & 5 \\
\hline (-) 31 . & 452 & 3.89 & 1.08 & .84 & 5 \\
\hline 32. & 452 & 3.30 & 1.13 & .84 & 5 \\
\hline Factor 2 & 452 & 41.18 & 7.72 & .85 & 55 \\
\hline 1. & 452 & 3.51 & 1.26 & .84 & 5 \\
\hline 2. & 452 & 4.24 & 1.02 & .84 & 5 \\
\hline 4. & 452 & 4.27 & 1.00 & .84 & 5 \\
\hline 5. & 452 & 3.67 & 1.16 & .84 & 5 \\
\hline 7. & 452 & 3.65 & 1.25 & .84 & 5 \\
\hline 9. & 452 & 3.26 & 1.26 & .84 & 5 \\
\hline 16. & 452 & 3.35 & 1.12 & .84 & 5 \\
\hline 18. & 452 & 3.85 & 1.05 & .84 & 5 \\
\hline 21. & 452 & 3.69 & 1.11 & .84 & 5 \\
\hline 23. & 452 & 3.66 & 1.13 & .84 & 5 \\
\hline 33. & 452 & 3.90 & 1.03 & .84 & 5 \\
\hline Factor 3 & 452 & 5.67 & 2.31 & .80 & 10 \\
\hline 26. & 452 & 3.00 & 1.30 & - & 5 \\
\hline 27. & 452 & 2.66 & 1.24 & - & 5 \\
\hline
\end{tabular}

Note: Reliability scores for factors are Cronbach's Alphas, and those for each of the items are Cronbach's Alphas if the item is deleted within each factor. Reversed items are shown with (-). 
their z-scores on Factor 1 were below -3.3 (Tabachnick \& Fidell, 2007), and these were excluded. The total number of participants in the ANOVAs was 449 .

A $2 \times 2$ ANOVA was conducted to evaluate the effects of academic major and gender on Factor 1. The means and standard deviations for this factor are presented in Table 4 along with those for the other two factors. The test of homogeneity of variance was non-significant $(p=$ .25 ), and the variances between the groups were not statistically significant. Homogeneity was assumed. The ANOVA indicated no significant interaction between major and gender, $F(1,445)=.39, p=.53$, and no significant main effects for gender, $F(1,445)=2.40, p=.12$, but it did show significant main effects for major, $F(1,445)=2.40, p<.017(.05 / 3)$. The effect size, however, was very small. This was measured by Partial $\eta^{2}$ and was .03. The students in the two departments were statistically significantly different in their scores on Emotionality with math majors being more anxious than social science majors. No gender difference was found and there were no interaction effects on the factor involving the two independent variables.

A second analysis was done between major and gender, and Factor 2 . The test of homogeneity of variance was non-significant $(p=.77)$, so both groups were assumed to be from the same population. The ANOVA results were not significant for all three sources-major, gender, and interaction between major and gender. The values were: $F(1,445)=.03, p=$ $.86 ; F(1,445)=.04, p=.85$; and $F(1,445)=1.61, p=.21$, respectively. The participants were not different in terms of the second factor, Worry.

A third $2 \times 2$ ANOVA was performed in relation to Factor 3. Homogeneity was assumed, with a $p$ value of .37 . The ANOVA results between academic major and the scores on Factor 3 were almost-but not quitesignificant: $F(1,445)=5.00, p=.03$. There was no significant difference between gender and Factor $3, F(1,445)=.02, p=.88$, and there were no interaction effects between the two independent variables and the factor scores, $F(1,445)=.02, p=.89$. The data are summarized in Table 4 and Table 5.

To recap, three factors were found in the FLLAS among Japanese learners of English. The two groups with different academic majors were indeed statistically different in their emotional reactions to the act of listening in English but not in their cognitive perception of anxietyprovoking situations or in their anticipation of worrisome situations and consequences. No gender difference was found. 
Table 4. Descriptive Statistics of Anxiety Over Listening in English in Terms of Academic Major and Gender Differences

\begin{tabular}{|c|c|c|c|c|c|c|c|c|}
\hline \multirow{3}{*}{$\begin{array}{l}\text { Descriptive } \\
\text { statistics }\end{array}$} & \multicolumn{3}{|c|}{ Factor 1} & \multicolumn{2}{|c|}{ Factor 2} & \multicolumn{3}{|c|}{ Factor 3} \\
\hline & SS & & $M A$ & $S S$ & $M A$ & $S S$ & & $M A$ \\
\hline & \multicolumn{3}{|c|}{ Total } & \multicolumn{2}{|c|}{ Total } & \multicolumn{3}{|c|}{ Total } \\
\hline \multicolumn{9}{|l|}{ Male } \\
\hline$M$ & 44.82 & & 48.83 & 40.49 & 41.76 & 5.38 & & 5.99 \\
\hline$S D$ & 8.36 & & 8.07 & 7.28 & 8.21 & 2.14 & & 2.61 \\
\hline \multicolumn{9}{|l|}{ Female } \\
\hline$M$ & 43.93 & & 46.74 & 41.43 & 40.49 & 5.45 & & 5.99 \\
\hline$S D$ & 8.86 & & 10.32 & 7.44 & 8.00 & 2.24 & & 2.41 \\
\hline \multicolumn{9}{|l|}{ Total } \\
\hline$M$ & 44.44 & & 48.46 & 40.89 & 41.53 & 5.41 & & 6.00 \\
\hline$S D$ & 8.57 & & 8.41 & 7.35 & 8.17 & 2.18 & & 2.60 \\
\hline \multicolumn{9}{|l|}{ Male } \\
\hline$M$ & & 46.97 & & & & & 5.71 & \\
\hline$S D$ & & 8.43 & & & & & 2.31 & \\
\hline \multicolumn{9}{|l|}{ Female } \\
\hline$M$ & & 44.63 & & & & & 5.59 & \\
\hline$S D$ & & 9.14 & & & & & 2.33 & \\
\hline \multicolumn{9}{|l|}{ Total } \\
\hline$M$ & & 46.23 & & & & & 5.67 & \\
\hline$S D$ & & 8.72 & & & & & 2.31 & \\
\hline
\end{tabular}

Note: SS stands for social science majors, and $M A$ stands for math majors. 
Table 5. Summary of Two-Way Analysis of Variance for Academic Major and Gender on Three Factors of FLLA

\begin{tabular}{lrrrrr}
\hline Source & $d f$ & \multicolumn{1}{c}{$S S$} & \multicolumn{1}{c}{$M S$} & \multicolumn{1}{c}{$F$} & $\eta^{2}$ \\
\hline Factor 1 & & & & & \\
Major & 1 & 911.23 & 911.23 & $12.63^{* *}$ & .03 \\
Gender & 1 & 172.95 & 172.95 & 2.40 & .01 \\
Major * Gender & 1 & 28.36 & 28.36 & .39 & .00 \\
Residual & 445 & 32101.75 & 72.14 & & \\
Factor 2 & & & & & \\
Major & 1 & 1.98 & 1.98 & .03 & .00 \\
Gender & 1 & 2.08 & 2.08 & .04 & .00 \\
Major * Gender & 1 & 96.01 & 96.01 & 1.61 & .00 \\
Residual & 445 & 26516.76 & 59.72 & & \\
Factor 3 & & & & & \\
Major & 1 & 26.51 & 26.51 & 5.00 & .01 \\
Gender & 1 & .13 & .13 & .02 & .00 \\
Major * Gender & 1 & .09 & .09 & .02 & .00 \\
Residual & 445 & 2360.87 & 5.31 & & \\
\hline Note: * $<.05 / 3$. & & & &
\end{tabular}

Note: ${ }^{* *} p<.05 / 3$.

\section{Discussion}

\section{Research Questions}

This study examined anxiety feelings that Japanese university students would experience in listening to English. The first research question concerned the measurement model for the Japanese-language version of the FLLAS. Thirteen items, related to the emotional elements involved in the act of listening in L2, loaded on Factor 1. Kim (2000) took the emotional component as language-specific lack of confidence. However, the items clustered in Factor 1, Emotionality, reflected not just lack of confidence but other emotional reactions as well: discomfort, dislike, annoyance, alienation, and intimidation. As a result, my broader term attempts to capture the full operational bandwidth of the factor. Item 19 seems to be confus- 
ing because translation involves a series of expository mental processes, but the phrase "end up" suggests that one has encountered a barrier to thinking-it indicates a stopgap solution and as such might be deemed to be outside of the realm of reasoning or cognitive assessment for the ongoing L2 listening task. Likewise, Items 17 and 29 refer to new information that listeners have to deal with, and which could throw their minds off balance. Item 15 is about the confusion caused when the memory load in the task of L2 listening is excessive. The participants who scored high in this factor were not comfortable in listening to English; they experienced arousal of negative feelings and emotions to the point of distress.

The second factor, Worry, appears to be basically related to the cognitive perceptions of the tasks at hand for L2 listeners. This factor garnered high loadings from 11 items that describe situations that may give rise to feelings of worry involved in processing the auditory information. Items 7 and 23 are about understanding the ideas expressed, and items 5 and 16 focus on world knowledge. Concerns about vocabulary are expressed in Items 1, 9, and 33, and the delivery of the message is the source of anxiety in Items 4, 18, and 21-speed, time allocation, and pace, respectively. At first sight, the items that are clustered together in Factor 2 vary in their properties, but all of the statements have something to do with cognition. These items indicate that participants are monitoring and evaluating what they are doing and how they are managing the specific tasks involved in L2 listening. They perceive difficulties in dealing with the information in terms of interpersonal and social expectations, which causes Worry. The perception of the task while in a state of worry may also interfere with effective processing of the language input, as observed in MacIntyre and Gardner (1991, 1994a, 1994b). It will diminish the listener's capacity to pay attention to the linguistic stimuli and the encoding and interpretation of the information.

The third factor, Anticipatory Fear, may be the most controversial, and indeed this factor did not surface in Kim's (2000) original research, nor has it surfaced in other anxiety constructs in SLA, but the loadings, .67 for Item 26 and .77 for Item 27, are the highest among the loadings of all the items. There are four possible explanations. First, the two items indicate the anticipatory aspect of anxiety as a psychological construct. Anxious feelings, especially the feeling of being worried, can be learned patterns of thinking, but they are also future-oriented. People feel worried because they know of possible negative outcomes, and because of this worry they try to avoid or withdraw from future encounters with similar situations. Thus, the items are about possible future events and should be 
distinguished from the other items. Second, listening is a highly anxietyprovoking activity in that listeners do not have as much control as do speakers, writers, or readers. Listeners cannot usually stop the aural flow of the incoming language or stop to think, and in this sense their locus of control becomes external rather than internal. This vulnerability may be the subject of the anticipatory aspect of anxiety being manifested. Item 26 refers to imagining oneself listening on the telephone, which can pose a very anxious situation for L2 listeners. Item 27 is also about listening to a lecture in L2, which the listener might expect to be incomprehensible. A third explanation might be found in the wording, as referred to in the results section. FLLA-J used the expression "souzou-suru" ("imagining"), which has to do with the learners using their imagination. This "imaginative" aspect might be emphasized with the connotation of fearful situations in the translation, in which the Japanese items stood out. It could therefore be considered an item-format effect.

One last explanation with respect to the third factor concerns the cultural aspect of learners' ways of thinking. Yamashiro and McLaughlin (2001) described this as the notion of "face" and collective thinking in interpersonal situations, which may cause Japanese learners of English to feel concerned about being evaluated by others or nervous about negative outcomes in L2 listening situations. The establishment of identity and self-presentation depends largely upon how others perceive us. These four possible accounts are all speculations, but their implications for future research may be worth exploring.

The second and third research questions are discussed in relation to group differences. University major did-although gender did not-make a difference in the anxiety scores in this study. Also, statistical significance was demonstrated with respect to the two independent variables only in Factor 1, Emotionality. Math students scored higher on this factor, but not on the others, Worry and Anticipatory Fear. It is not clear why students in different departments displayed different patterns with respect to Factor 1, but they might be distinct in their studying orientations or approaches to learning. Such difference has been detected in Andreou, Andreou, and Vlachos (2004) in SLA, and in Drew and Watkins (1998) and Ramsden and Entwistle (1981) in education. This line of argument in EFL and ESL settings awaits further research, but considering the small effect size in the variable "major" and on only one factor, it is arguable that the occurrence of FLLA is a function of a variety of person-specific, group-related, and situational variables. Person-specific variables could include personality, tendency to feel anxiety, self-knowledge, and past 
language-learning experience, among others. Some of the potential group differences can be race, gender, age, university major, and first language. Situational variables could be interpersonal or related to specific listening tasks. Temporal factors such as fatigue and disturbance might also have to be considered. L2 listeners may experience discomfort to different degrees and for diverse reasons or combinations of reasons. At the same time, all of the participants were from the two departments of the same university, and thus they were not dissimilar enough to diverge in terms of these three factors identified in the FLLAS.

\section{Implications}

Anxiety research in educational psychology and social psychology has reported that skills-acquisition treatments were effective in the cognitive aspect of anxiety, Worry, and that desensitization and relaxation worked better in the reduction of Emotionality (Leary \& Kowalski, 1995; Morris, et al., 1981; Zeidner, 1998). These results indicate that in this particular teaching/ learning context, strategy training and awareness-raising in L2 listening strategies would be promising for learners in both departments to help reduce the level of anxiety, and that a reassuring environment might be necessary, especially for math majors. In the area of SLA, learners who participated in the Vogely (1998) study cited inappropriate strategies as a source of listening-related anxiety, and this idea is consistent with the findings of this study.

Some recent studies performed in EFL settings in Japan have examined anxiety-reducing measures and learner emotions. Kondo and Ying-Ling (2004) demonstrated that the overall level of anxiety and the frequency of strategy use were negatively correlated and that active, problem-focused coping measures can be effective. A descriptive study conducted by Tani-Fukuchi (2005) was intriguing in that 68 percent of her participants reported negative feelings such as anxiety, tense feelings, confusion, discomfort, resistance, and apathy, among others, while only 18 percent reported that they had experienced positive emotions while learning English. The author stated that this predominance of negative emotions should be dealt with and that treatment measures must be incorporated into curriculum and program planning. However, neither study took into account the ideas that learners might not be unitary in the dimensional formulation of their nervous feelings and that the composition of factors influencing anxious feelings might also be as important as the strength of those feelings. 
Language-learning anxiety has been investigated in different skill domains, which represents a movement toward greater sophistication of research in this field. However, feelings of worry aroused in association with language learning may well have some characteristics in common across skill areas and across situations. In addition, it has been reported that socially anxious individuals tend to experience fear in multiple situations (Heimberg, Liebowitz, Hope, \& Schneider, 1995). Just emphasizing the specificity might not be as rewarding as it looks. One way of measuring specificity $\mathrm{v}$. generality would be to test participants using both general trait-anxiety scales and situation-specific scales like the FLLAS, and then examine the extent to which the general trait measure predicts the situational measure. In this study, L2 listening anxiety was shown to be susceptible to group differences. In future research, it will be necessary to investigate situational differences as well as social and cultural influences and their changes over time.

There are some limitations to this study that need to be pointed out. One is that the number of participants was not well balanced either between the two academic majors or in terms of gender (see Table 1). Another limitation is the small number of items that were clustered in Factor 3. Still another caution concerns the wording of items on the scale. In affective scales, which try to tap into learner psychology, subtle connotations and combinations of words used in items will affect the responses and thus the participants' scores.

\section{Conclusion}

Listening in a foreign language can be anxiety-provoking, even though listening is a receptive skill. The anxiety felt by L2 listeners seems to have features specific to listening in L2 but also common underlying characteristics that are shared by emotionally and cognitively distressed people generally-namely, Emotionality and Worry. Also, the anticipatory aspect of L2 listening might be another feature influencing learners' psychological state: Anticipatory Fear. In this study, university major was found to have a statistically significant effect on the level of Emotionality.

\section{Acknowledgements}

I would like to express my sincere gratitude to all the participants in this study for their cooperation and my teachers at Temple University Japan for their dedicated support. I am also deeply grateful to the editors, 
Steve Cornwell and Ian Isemonger, and the two anonymous reviewers for their insightful comments and helpful suggestions. Any shortcomings and mistakes are mine.

Harumi Kimura studies at Temple University, Japan. Her research interests range from cooperative learning to psychology of language learners.

\section{References}

Andreou, E., Andreou, G., \& Vlachos, F. (2004). Studying orientations and performance on verbal fluency tasks in a second language. Learning and Individual Differences, 15, 23-33.

Arnold, J. (2000). Seeing through listening comprehension exam anxiety. TESOL Quarterly, 34, 777-786.

Campbell, C. M. (1999). Language anxiety in men and women: Dealing with gender difference in the language classroom. In D. J. Young (Ed.), Affect in foreign language and second language learning: A practical guide to creating a lowanxiety classroom atmosphere (pp. 191-215). Boston: McGraw Hill.

Cheng, Y. S., Horwitz, E. K., \& Schallert, D. L. (1999). Language writing anxiety: Differentiating writing and speaking components. Language Learning, 49, 417-446.

Dörnyei, Z. (2002). Motivation, anxiety and emotion in second language acquisition. In P. Robinson (Ed.), Individual differences and instructed language learning (pp. 45-68). Amsterdam: John Benjamins.

Dörnyei, Z. (2005). The psychology of the language learner: Individual differences in second language acquisition. Mahwah, NJ: Lawrence Erlbaum.

Drew, P. Y., \& Watkins, D. (1998). Affective variables, learning approaches and academic achievement: A causal modelling investigation with Hong Kong tertiary students. British Journal of Educational Psychology, 68, 173-188.

Field, A. (2005). Discovering statistics using SPSS ( $2^{\text {nd }}$ ed.). Thousand Oaks, CA: Sage Publications.

Heimberg, R. G., Liebowitz, M. R., Hope, D. A., \& Schneider, F. R. (1995). Social phobia: Diagnosis, assessment, and treatment. New York: The Guilford Press.

Henson, R. K., \& Roberts, J. K. (2006). Use of exploratory factor analysis in published research: Common errors and some comment on improved practice. Educational and Psychological Measurement, 66, 393-416.

Horwitz, E. K. (1986). Preliminary evidence for the reliability and validity of a foreign language anxiety scale. TESOL Quarterly, 20, 559-562.

Horwitz, E. K. (2001). Language anxiety and achievement. Annual Review of Applied Linguistics, 21, 112-126. 
Horwitz, E. K., Horwitz, M. B., \& Cope, J. (1986). Foreign language classroom anxiety. The Modern Language Journal, 70, 125-132.

Kim, J.-H. (2000). Foreign language listening anxiety: A study of Korean students leaning English. Unpublished doctoral dissertation, The University of Texas, Austin.

Kitano, K. (2001). Anxiety in the college Japanese language classroom. The Modern Language Journal, 85(4), 549-566.

Kleinmann, H. H. (1977). Avoidance behavior in adult second language acquisition. Language Learning, 27(1), 93-107.

Kondo, D. S., \& Ying-Ling, Y. (2004). Strategies for coping with language anxiety: The case of students of English in Japan. ELT Journal, 58, 258-265.

Leary, M. R., \& Kowalski, R. M. (1995). Social anxiety. New York: The Guilford Press.

Liebert, R. M., \& Morris, L. W. (1967). Cognitive and emotional components of test anxiety: A distinction and some initial data. Psychological Reports, 20, 975-978.

MacIntyre, P. D. (1995). How does anxiety affect second language learning? A reply to Sparks and Ganschow. The Modern Language Journal, 79, 91-99.

MacIntyre, P. D. (1999). Language anxiety: A review of the research for language teachers. In D. J. Young (Ed.), Affect in foreign language and second language learning: A practical guide to creating a low-anxiety classroom atmosphere (pp. 24-45). Toronto: McGraw-Hill.

MacIntyre, P. D. (2002). Motivation, anxiety, and emotion in second language acquisition. In P. Robinson (Ed.), Individual differences and instructed language learning (pp. 45-68). Amsterdam: John Benjamins.

MacIntyre, P. D., Baker, S. C., Clément, R., \& Donovan, L. A. (2002). Sex and age effects on willingness to communicate, anxiety, perceived competence, and L2 motivation among junior high school French immersion students. Language Learning, 52(3), 537-564.

MacIntyre, P. D., \& Gardner, R. C. (1989). Anxiety and second language learning: Toward a theoretical understanding. Language Learning, 39, 251-275.

MacIntyre, P. D., \& Gardner, R. C. (1991). Language anxiety: Its relation to other anxieties and to processing in native and second languages. Language Learning, $41,513-534$.

MacIntyre, P. D., \& Gardner, R. C. (1994a). The effects of induced anxiety on three stages of cognitive processing in computerized vocabulary learning. Studies in Second Language Acquisition, 16, 1-17.

MacIntyre, P. D., \& Gardner, R. C. (1994b). The subtle effects of language anxiety on cognitive processing in the second language. Language Learning, 44(2), 283-305.

Matsuda, S., \& Gobel, P. (2001). Quiet apprehension: Reading and classroom anxieties. JALT Journal, 23(2), 227-247. 
Matsuda, S., \& Gobel, P. (2004). Anxiety and predictors of performance in the foreign languageclassroom. System, 32(1), 21-36.

Morris, L. W., Davis, M. A., \& Hutchings, C. H. (1981). Cognitive and emotional components of anxiety: Literature review and a revised worry-emotionality scale. Journal of Educational Psychology, 73(4), 541-555.

Ramsden, P., \& Entwistle, N. J. (1981). Effects of academic departments on students' approaches to studying. British Journal of Educational Psychology, 51, 368-383.

Saito, Y., Horwitz, E. K., \& Garza, T. J. (1999). Foreign language reading anxiety. The Modern Language Journal, 83, 202-218.

Scovel, T. (1978). The effect of affect on foreign language learning: A review of the anxiety research. Language Learning, 28, 129-142.

Tabachnick, B. G., \& Fidell, L. S. (2007). Using multivariate statistics (5th ed.). Boston: Pearson Education.

Tani-Fukuchi, N. (2005). Japanese learner psychology and assessment of affect in foreign language study. The Language Teacher, 29(4), 3-9.

Vogely, A. J. (1998). Listening comprehension anxiety: Students' reported sources and solutions. Foreign Language Annals, 31, 67-80.

Wheeless, L. R. (1975). An investigation of receiver apprehension and social context dimensions of communication apprehension. The Speech Teacher, 24, 261-268.

Yamashiro, A., \& McLaughlin, J. (2001). Relationships among attitudes, motivation, anxiety, and English language proficiency in Japanese college students. In P. Robinson, M. Sawyer, \& S. Ross (Eds.), JALT applied materials: Second language acquisition research in Japan (pp. 113-127). Tokyo: JALT.

Young, D. J., \& Oxford, R. L. (1997). A gender-related analysis of strategies used to process written input in the native language and a foreign language. Applied Language Learning, 8, 43-73.

Zeidner, M. (1998). Test anxiety: The state of the art. New York: Plenum Press. 


\section{Appendix A}

\section{Japanese Translation of Foreign Language Listening Anxiety (FLLAS-J)}

1. 英語を聞くとき、1つか 2 つの知らない単語にとまどってしまう。

2. 英語のリスニングテストが一回しか読まれないと緊張する。

3. 日本人の話す英語は分かりやすいが、それ以外の英語を聞くのは難しい。

4. あまりに早く英語で話されると、全部理解できないのではないかと不安にな る。

5.よく知らないトピックについて英語で聞くのは、落ち着かない。

6. 英語を聞き逃しても、そこの意味を推測するのは簡単だ。

7.リスニング中に少しでも気が散ってしまうと、大切な点を聞き逃したのではな いかと心配になる。

8.リスニング中に話者の口や表情が見えないと不安になる。

9. リスニングテストの最中、1つ 1 つの単語を理解できないと緊張するし混乱す る。

10. 英語の聞き取りでは、1つ 1 つの単語を区別するのが難しい。

11. スクリプトなしで英語を聞くのは落ち着かない。

12. 口頭で行われる英語の指示についていくのは大変だ。

13. 話し手が自分のよく知らない人だと、集中して聞けない。

14. 英語のリスニングには自信がある。

15. 英語を聞くと混乱して、何を聞いたか覚えていられないことが多い。

16. リスニングの際、そのトピックの不十分な知識に不安になる。

17. 英語で重要な情報を聞いていると、頭が混乱してしまう。

18. 英語で聞いた内容に関してあまり考える時間がないと、心配になる。

19. 英語を聞いているとき、内容を理解せずに 1 つ 1 つの単語を訳してしまって いることがよくある。

20. できれば、人の話は英語で聞きたくない。

21. 自分のペースで英語が聞けないと、不安になる。

22. 自分以外の人は英語をよく理解していると、いつも思ってしまう。

23. 自分が英語を正確に理解したかどうかわからないとき、焦ってしまう。

24. 小さな声で英語を話されると、理解できていないのではないかと心配にな る。

25. 聴衆のひとりとしてなら、英語を聞くことに不安はない。

26. 電話で英語を聞くときや、その場面を想像してみただけでも、緊張する。

27. 講演会などで英語を聞いたり、その場面を想像してみただけでも、緊張する。

28. 少しでも騒音があると、英語は聞き取りにくい。

29. 英語で新しい情報を聞くのは不安だ。

30. 英語を聞いていて、理解できない単語に出会うといらいらする。

31. 英語の強弱(ストレス)やイントネーションには慣れている。

32. 英語のリスニングで、単語は理解できても話し手の言いたいことは理解でき ていないことが多い。

33.リスニングでキーワードが聞き取れないと心配になる。 


\section{Appendix B}

Back-translation of Foreign Language Listening Anxiety (FLLAS-J)

\section{When listening to English:}

1. I get stuck with one or two unfamiliar words.

2. I get nervous if listening test passages are read just once.

3. It is difficult to understand people with English pronunciation that is different from mine.

4. I worry that I might not be able to understand when people talk too fast.

5. I am nervous when I'm not familiar with the topic.

6. It is easy to make guesses about the parts I missed.

7. I worry that I might have missed important information while I was distracted.

8. I am worried when I cannot see the lips or facial expressions of the person.

9. I get nervous and confused when I don't understand every word in listening test situations.

10. It is difficult to differentiate words.

11. I feel uncomfortable listening without a chance to read the transcript of the speech.

12. I have difficulty in understanding oral instructions.

13. It is difficult to concentrate on and hear a speaker I do not know well.

14. I feel confident in my listening skills.

15. I often get so confused that I cannot remember what I have heard.

16. I fear I might have an inadequate knowledge about the topic.

17. My thoughts become jumbled and confused in listening for important information. 
18. I get worried when I have little time to think about what I have heard.

19. I often end up translating word by word without understanding what I'm listening to.

20. I would rather not listen to people talking in English.

21. I get worried when I cannot listen at the pace I'm comfortable with.

22. I tend to think that other people understand the content well enough.

23. I get upset when I'm not sure whether I have understood well.

24. I am worried I might not understand when the person lowers their voice while speaking in English.

25. I have no fear of listening to public speeches in English.

26. I am nervous when listening to English over the phone or when imagining myself listening over the phone.

27. I feel tense when listening to, or imagining myself listening to, a lecture.

28. I have difficulty when the environment around me is noisy.

29. Listening to new information makes me uneasy.

30. I get annoyed when I come across new words.

31. English stress and intonation patterns are familiar to me.

32. It often happens that I do not understand what English speakers say.

33. The thought that I may be missing key words frightens me.

Note. The original English translation from Korean was published in Kim (2000). 
